\title{
The protease-activated receptor 1 inhibition during epileptogenesis does not alter behavioral excitability in rats
}

\author{
O.O. Lunko1 ${ }^{1}$, R.I. Bogovyk ${ }^{1}$, M.P. Fedoriuk ${ }^{1}$, G.S. Semenets ${ }^{2}$, E.V. Isaeva ${ }^{1,2}$ \\ ${ }^{1}$ Bogomoletz Institute of Physiology, National Academy of Sciences of Ukraine, Kyiv; \\ ${ }^{2}$ Taras Shevchenko National University of Kyiv; e-mail: lunko@biph.kiev.ua
}

\begin{abstract}
Antiepileptic drugs can induce both positive and adverse psychotropic effects, therefore evaluation of the behavioral effects of potential antiepileptic treatment early in the screening process is essential. Recently, we have shown that antagonist of protease-activated receptor 1 (PAR1), a major thrombin receptor in CNS, exhibits antiepileptogenic effect in the experimental model of temporal lobe epilepsy (TLE) reducing animal mortality, decreasing cell loss in hippocampal CA1 pyramidal region and probability of spontaneous recurrent seizures. PARI inhibition also improves contextual and cued fear learning and restores the control level of anxiety-related behavior in rats experiencing status epilepticus (SE). The aim of the present study was to determine the effect of PARI inhibition on the behavioral excitability of rats after SE. The experimental model of TLE was induced using intraperitoneal injections of lithium and pilocarpine. After that rats were treated with PAR1 inhibitor, SCH79797, for ten consecutive days. A battery of behavioral tests (approach-test, pick-up test, and touch-response test) was used for evaluation of behavioral hyperexcitability. We have found that SE induced different signs of the disturbance of behavior in response to sensory stimuli in pick-up test (average score of the test was $3.1 \pm 0.6$ in control animals and $5.2 \pm 0.1$ in animals with $S E$ ) and touch-response test (average score was $2.6 \pm 0.6$ and $5.7 \pm 0.4$ in rats without and with SE respectively). PAR1 inhibition did not affect the behavioral excitability of experimental rats. There was no significant difference between experimental groups in approach-test. Our results suggest the PAR1-independent development of disturbances of sensorimotor reactions during epileptogenesis in the current experimental model of TLE.

Key words: protease-activated receptor type 1; SCH79797; lithium-pilocarpine model; status epilepticus; behavioral hyperexcitability.
\end{abstract}

\section{INTRODUCTION}

The most common form of epilepsy in adults, temporal lobe epilepsy (TLE), is frequently accompanied by a variety of cognitive and psychiatric disorders, such as depression, fear, panic, hostility, aggression, and anger [1]. The effect of such comorbidities is often comparable with the main complications of the disease. There are several reasons that could be accounted for the development of such comorbidities in patients with TLE. First, TLE is associated with pathological alterations in the limbic system, including limbic cortex, amygdala, hippocampal formation, septal area and hypothalamus - structures, which form a complex network for processing emotions, fear learning and memory formation. Second, most of currently used antiepileptic drugs cause some degree of behavioral side effects. Therefore, testing of the new potential antiepileptic compounds should be accompanied with the rigorous analysis of the effect of such treatment on the behavior.

Recently we have shown that inhibition of the major thrombin receptor in the brain, protease-activated receptor 1 (PAR1), shortly after status epilepticus (SE) results in neuroprotective and antiepileptogenic effects in the classical experimental model of TLE [2]. PAR1 belongs 
to the family of G-protein coupled receptors and has the unique activation mechanism. This receptor has its own ligand sequence on the extracellular N-terminus which uncovers upon proteolysis by different serine proteases, including thrombin and plasmin [3]. PAR 1 is widely expressed in limbic system including amygdala, hippocampus, as well in cortex, cerebellum, thalamus, hypothalamus [4]. It is implicated in alteration of voltage-gated channel properties $[5,6]$, synaptic transmission and synaptic plasticity [7-9]. Also, PAR1 was shown to play the role in the regulation of emotionally driving learning [10] and in the pathogenesis of different neurological disorders [11-14]. The aim of the present study was to determine the effect of PAR1 inhibition on the chronic alteration of behavioral excitability of rats after SE.

\section{METHODS}

All procedures were done in accordance with the Directive of European Parliament and Council $2010 / 63 /$ EU on the protection of animals for scientific purposes and approved by the Committee of Biomedical Ethics of Bogomoletz Institute of Physiology of the National Academy of Sciences of Ukraine.

\section{Lithium-pilocarpine model of TLE}

Male Wistar rats aged 50-60 days were used throughout the study. Animals were kept in 12 $\mathrm{h}$ light/dark cycle with ad libitum access to the food and water. The method of SE induction using muscarinic receptor agonist, pilocarpine, was described previously [2]. Briefly, rats were treated with $\mathrm{LiCl}(127 \mathrm{mg} / \mathrm{kg})$ dissolved in $0.9 \%$ saline 19-20 hours before the pilocarpine administration. SE was induced using the protocol of repetitive intraperitoneal (i.p.) injections of small doses of pilocarpine to reduce animal mortality [15]. Pilocarpine was injected in thirty minutes intervals with an initial dose $30 \mathrm{mg} / \mathrm{kg}$ and following doses $10 \mathrm{mg} / \mathrm{kg}$. Pilocarpine injections were discontinued after animal developed stages IV-V of epileptic seizures according to the Racine scale
[16]. Animals that did not develop SE after five consecutive pilocarpine injections ( 3 of 29, 10,3 $\%$ ) were excluded from the study. Ninety minutes after SE initiation epileptic seizures were terminated by sevoflurane. Eight weeks after SE initiation, rats were video monitored for spontaneous seizures (12 hours per day for 6 days).

\section{SCH79797 treatment}

PAR1 antagonist (SCH79797, $10 \mathrm{mM}$ in 96\% EtOH) was diluted in $0.9 \%$ saline to the concentration $25 \mu \mathrm{g} / \mathrm{kg}$. SCH79797 (group "SE+SCH") or appropriate volume of saline (group "SE") were administered once a day during ten days after SE initiation. Control rats were injected with the vehicle instead of pilocarpine and received similar treatment with SCH79797 (group "Control+SCH") or appropriate volume of saline (group "Control”) as SE groups.

\section{Behavioral tests on hyperexcitability}

To evaluate the effect of PAR1 inhibition on behavioral excitability and sensory responsiveness all experimental groups underwent a battery of behavioral tests nine weeks after study entry [17-19]. We conducted three behavioral tests: approach test, pick-up test and touch test as described by Rice et al. [20]. Results were scored to following behavioral reactions on stimuli:

1. Approach-response test. A pencil in vertical position slowly and gradually moved in the direction to the face of the animal. Results of the test were scored in accordance to the following reactions: the animal does not react to the object (1 score); the animal returns to the direction of the object and sniffs (2 scores); the animal avoids the object and moves away from the object ( 3 scores); the animal freezes (4 scores); the animal jumps from the object ( 5 scores); the animal jumps toward the object or attacks it (6 scores).

2. Pick-up test. The animal is elevated by grasping around the body. Results of the test were scored in accordance to the following reactions: the animal is grasped and elevated easily ( 1 score); the animal is grasped and elevated easily but with vocalization ( 2 scores); 
grasping and elevating the animal requires some efforts, the animal faces to the hands (3 scores); during elevation the animal freezes with or without vocalization (4 scores); it is difficult to grasp and elevate the animal, the animal runs away from the hand ( 5 scores); it is very difficult to handle and elevate the animal, the animal takes defensive position and may attack the hand (6 scores).

3. Touch-response test. The animal is accurately touched at the basement of the tail by blunt side of the pencil. Results of the test were scored in accordance to the following reactions: the animal does not react to the touch (1 score); the animal returns and faces to the pencil ( 2 scores); the animals moves away from the pencil (3 scores); the animal freezes after the touch (4 scores); the animal startles with jump after the touch ( 5 scores); the animal runs away from the touch (6 scores); the animal jumps away from the touch with vocalization (7 scores).

All behavioral tests were performed in the home cage. Each behavioral test was conducted by three investigators "blinded" to the animal treatment conditions with an interval one hour between trials. The final score of each test for each rat was calculated as the median of the scores obtained by each investigator [21].

\section{Statistics}

Statistical analysis was performed using GraphPad Prism ("GraphPad Software", CA, USA). All values in the study were expressed as standard error of the mean. Values of the median for every group are shown as a horizontal line. For the statistical analysis, Kruskal-Wallis non-parametric test (one-way ANOVA on ranks) was used followed by Dunn's pairwise multiple comparisons post-hoc test for individual differences. Differences were considered statistically significant if $\mathrm{P}<0.05$.

\section{RESULTS}

Nine out of twelve rats developed spontaneous seizures $(75.0 \%)$ in the "SE" group and six out of fourteen $(42.9 \%)$ in the "SE + SCH" group. Visual observation revealed that upon the recovery after SE rats had elevated hyperexcitability and disturbed exploratory behavior. Our recent report, using PAR1 inhibition paradigm, revealed that rats with a history of pilocarpine-induced SE were more active in open field and elevated plus-maze and had deficits in contextual and cued fear learning compared to control animals [22]. To determine whether PAR 1 inhibition affects behavioral excitability of experimental animals in the present study we conducted three tests: approach-response test, pick-up test, and touch-response test, which were reported to discriminate animals with and without SE in both chemoconvulsant and electrically evoked models of epilepsy [18, 19].

SE and/or PAR1 inhibition does not affect the animal performance in approach-response test (Fig.1). Mean scores were $1.8 \pm 0.3,2.8$ $\pm 0.5,2.4 \pm 0.4$ and $2.4 \pm 0.3$ for "Control", "Control+SCH", "SE" and "SE+SCH" groups respectively. For pick-up test, ANOVA revealed a significant group difference in animal behavior $(\mathrm{F}(3,44)=13.08, \mathrm{P}<0.01)$. The average score for "Control" group $(\mathrm{n}=10)$ was $3.1 \pm 0.6$ whereas in "SE" group $(\mathrm{n}=12)$ the average score was 5.2 \pm 0.1 (Fig. 2, $\mathrm{P}<0.05$, post hoc multiple comparisons Dunn's test). SCH79797 treatment does not affect the performance of control (average score was $4.0 \pm 0.5$ for "Control $+\mathrm{SCH}$ " group, $\mathrm{n}=12$ ) as well as SE (average score was $5.1 \pm$ 0.2 for "SE+SCH" group, $\mathrm{n}=14$ ) group animals in this test ("Control" vs "Control+SCH": $\mathrm{P}>0.9$, "SE" vs "SE+SCH": P >0.9). ANOVA test also revealed a significant group difference in animal behavior in the touch-response test $(\mathrm{F}(3,44)=16.52, \mathrm{P}<0.001$, Fig. 3$)$. Mean scores were $2.6 \pm 0.6,3.7 \pm 0.6,5.7 \pm 0.4$ and $5.6 \pm 0.4$ for "Control", "Control+SCH", "SE" and "SE+SCH" groups respectively. Dunn's post hoc analysis revealed that the "SE" group was significantly more sensitive to touch compared to the "Control" group $(\mathrm{P}<0.05)$. We did not observe the difference in the average score level in the touch-response test between groups 


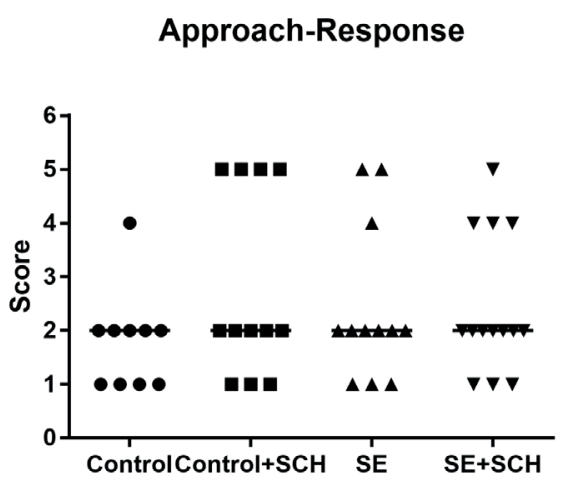

Fig. 1. The effect of PAR1 inhibition on animal behavior during approach-response test. No significant difference in the mean score was observed between experimental groups at nine weeks after SE

treated with SCH79797 ("Control+SCH" and "SE+SCH", $\mathrm{P}>0.05$ ) and corresponding groups without PAR1 antagonist treatments ("Control" and "SE" respectively, $\mathrm{P}>0.05)$.

\section{DISCUSSION}

In the present study, rats experienced SE and controls exerted different sensitivity to three behavioral tests employed. Our data demonstrate that rats with the history of SE show an enhanced excitability in both pick-up and touch-response tests, whereas no difference in response to the approach test was found between all experimental groups. These data are in agreement with

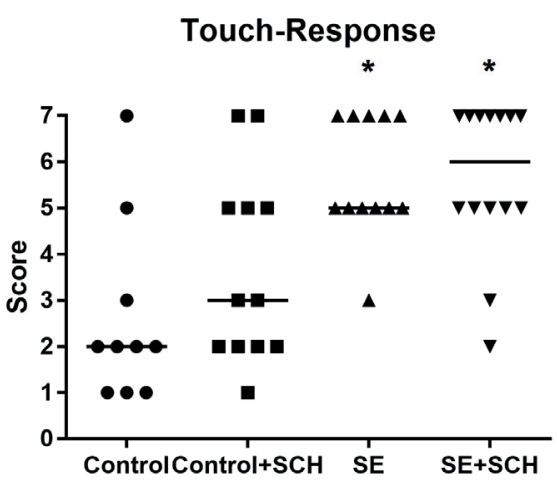

Fig. 3. The effect of PAR1 inhibition on animal behavior during touch-response test. Rats with a history of SE show the significant increase in the mean score compared to controls. PAR1 inhibition had no effect on animal behavior in this test. $* \mathrm{P}<0.01$ compared to control group

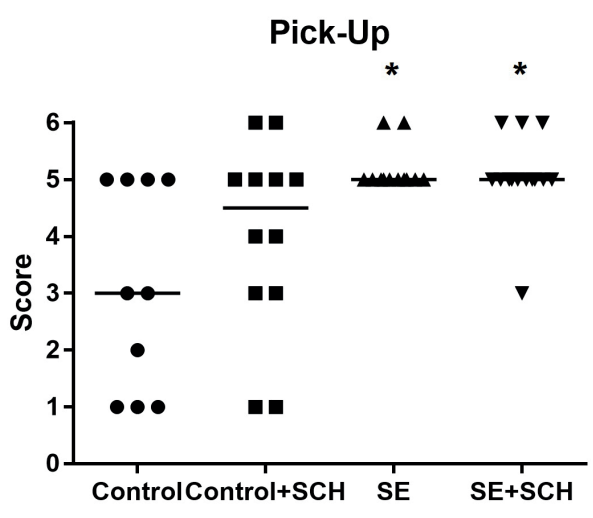

Fig. 2. PAR1 inhibition does not affect alteration of epileptic animal behavior during pick-up test. $* \mathrm{P}<0.05$ compared to control group

previous studies using pilocarpine and lithiumpilocarpine models of TLE $[19,20]$. However, it was reported that the pick-up test is the most sensitive for discriminating SE-experienced rats from control rats $[23,24]$. Also, using a similar approach to evaluate behavioral excitability in young epileptic rats, Huang et al. [25] have shown that pilocarpine-treated rats exhibited more aggressive behavior in all three tests employed. Such discrepancies in the behavioral reactions could be explained by different animal sex, age, strain or vendor. Indeed, genetic background and epigenetic variability may have a significant effect on post-SE outcome both at cellular level [26] and in behavior [27].

In our study, the inhibition of PAR1-mediated signaling does not alter behavioral excitability of rats with and without SE experience. The underlying mechanisms of antiepileptogenic and neuroprotective effect of PAR1 inhibition are not completely understood [2]. In one possible mechanism, the inhibition of PAR1-dependent signaling could affect SE-induced alteration of the neuronal excitability through modulation of intrinsic neuronal excitability and synaptic transmission [5, 8]. Another mechanism could implicate the anti-inflammatory effect of PAR 1 inhibition after SE. It is well established that PAR1 is involved in the inflammatory signaling. PAR1 activation has been shown to induce 
cyclooxygenase-2 (COX-2) expression and prostaglandin $\mathrm{E} 2$ release, and regulate mechanistic target of rapamycin (mTOR) signaling pathway [28]. Interesting, that the inhibition of mTOR signaling by rapamycin produced very similar effect on epileptogenic process as we recently reported using PAR1 inhibition [2, 8]. Huang and colleagues have shown that mTOR inhibition prevents the development of spontaneous recurrent seizures and has a neuroprotective effect in an acquired epilepsy model [29]. Moreover, injection of rapamycin in the chronic stage resulted in the significant improvement in behavioral hyperexcitability of epileptic rats. However, this positive effect on the behavior was only transient and gradually reversed within a week after termination of rapamycin treatment [25]. We suggest that the effect of PAR1 inhibition on epileptogenic process and behavioral outcomes could be at least partially explained by alteration of inflammatory pathway.

\section{CONCLUSIONS}

In summary, our data revealed that PAR1 inhibition does not affect the behavioral excitability in rats with and without history of SE. These data suggest that mechanisms underlying induction of hyperexcitability after SE induced by lithium and pilocarpine does not implicate mechanisms mediated by PAR1 signaling.

The authors of this study confirm that the research and publication of the results were not associated with any conflicts regarding commercial or financial relations, relations with organizations and/or individuals who may have been related to the study, and interrelations of coauthors of the article.

\section{О.О. Лунько ${ }^{1}$, Р.І. Боговик ${ }^{1}$, М.П. Федорюк ${ }^{1}$, Г.С. Семенець ${ }^{2}$, О.В. Ісаєва ${ }^{1,2}$ \\ ПРОТЕАЗОАКТИВОВАНИЙ РЕЦЕПТОР 1 НЕ ВПЛИВАС НА ПОВЕДІНКОВУ ЗБУДЛИВІСТЬ У ЩУРІВ 3 ЕПІЛЕПТИЧНИМ СТАТУСОМ}

Вивчали вплив інгібітора протеазоактивованого рецептора 1 (ПАР1) на збудливу поведінку щурів після епілептичного статусу (ЕС). Експериментальну модель скроневої епілепсії (CE) індукували з використанням літію та пілокарпіну. Після цього щурам здійснювали ін'єкції інгібітора ПАР1, $\mathrm{SCH79797,} \mathrm{протягом} 10$ послідовних днів. Для оцінки збудливої поведінки були проведені поведінкові тести на сенсорні подразнення, а саме: на наближення предмета до тварини, на піднімання тварини, на доторк до тварини. Ми встановили, що ЕС викликає різні ознаки порушення поведінки щурів у відповідь на сенсорні подразники в тестах на піднімання (середній бал тесту становив 3,1 \pm 0,6 у контрольних тварин та 5,2 $\pm 0,1$ у тварин з ЕС) та на доторк до тварини (середній бал був 2,6 \pm 0,6 та 5,7 \pm 0,4 відповідно у щурів без та з ЕС). Інгібування ПАР1 не впливало на зміни у поведінковій збудливості піддослідних щурів. У тестах на наближення предмета до тварини не було виявлено достовірної різниці між експериментальними групами. Наші результати дають підстави припустити, що розвиток сенсомоторних розладів у щурів під час епілептогенезу не залежить від ПАР1 у такій моделі СЕ. Ключові слова: протеазоактивований рецептор 1; SCH79797; літій-пілокарпінова модель; епілептичний статус; поведінкова збудливість.

${ }^{1}$ Інститут фізіології ім. О. О. Богомольия НАН Украӥни, Київ;

${ }^{2}$ Київський Національний університет

ім. Тараса Шевченка; e-mail: lunko@biph.kiev.ua

\section{А.А. Лунько, Р.И. Боговик, М.П. Федорюк, А.С. Семенец, Е.В. Исаева \\ ПРОТЕАЗОАКТИВИРОВАННЫЙ РЕЦЕПТОР 1 НЕ ВЛИВЯЕТ НА ПОВЕДЕНЧЕСКУЮ ВОЗБУДИМОСТЬ У КРЫС С ЭПИЛЕПТИЧЕСКИМ СТАТУСОМ}

Изучали влияние ингибитора протеазоактивированного рецептора 1 (ПАР1) на поведенческие реакции крыс после эпилептического статуса (ЭС) в ответ на сенсорные раздражители. Экспериментальную модель височной эпилепсии (ВЭ) индуцировали с использованием лития и пилокарпина. После этого крысам осуществляли инъекции ингибитора ПАР1, SCH79797, на протяжении 10 последовательных дней. Для оценки возбудимого поведения были проведены поведенческие тесты на сенсорные раздражения, а именно: на приближение предмета к животному, на поднятие животного, на прикосновение к животному. Мы установили, что ЭС вызывает различные признаки нарушения поведения крыс в ответ на сенсорные раздражители в тестах на поднятие (средний бал теста составлял $3,1 \pm 0,6$ у контрольних животных и $5,2 \pm 0,1$ у животных с ЭС) и на прикосновение к животному (средний бал был $2,6 \pm 0,6$ и 5,7 $\pm 0,4$ соответственно у крыс без и с ЭС). Ингибирование ПАР1 не влияло на изменения в поведенческой возбудимости подопытных крыс. В тестах на приближение предмета к животному не было выявлено достоверной разницы между экспериментальными группами. Наши результаты дают основания предположить, 
что развитие сенсомоторных расстройств у крыс во время эпилептогенеза не зависит от ПАР1 в данной модели ВЭ. Ключевые слова: протеазоактивированный рецептор 1; SCH79797; литий-пилокарпиновая модель; эпилептический статус; поведенческая возбудимость.

\section{REFERENCES}

1. Tellez-Zenteno JF, Patten SB, Jetté N, Williams J, Wiebe S. Psychiatric comorbidity in epilepsy: A population-based analysis. Epilepsia. 2007; 48:2336-44.

2. Isaev DS, Lushnikova IV, Lunko OO, Zapukhliak O, Maximyuk OP, Romanov AK, Skibo GG, Tian C, Holmes $\mathrm{GL}$, Isaeva EV. Contribution of protease-activated receptor 1 in status epilepticus-induced epileptogenesis. Neurobiol Dis. 2015; 78:68-76.

3. Soh UJ, Dores MR, Chen B, Trejo J. Signal transduction by protease-activated receptors. Br J Pharmacol. 2010; 160:191-203.

4. Bourgognon J-M, Schiavon E, Salah-Uddin H, et al. Regulation of neuronal plasticity and fear by a dynamic change in PAR1-G protein coupling in the amygdala. Mol Psychiatry. 2013; 18:1136-45.

5. Isaeva E, Hernan A, Isaev D, Holmes GL. Thrombin facilitates seizures through activation of persistent sodium current. Ann Neurol. 2012; 72:192-8.

6. Lunko OO, Isaev DS, Krishtal OO, Isaeva EV. Thrombin modulates persistent sodium current in CA1 pyramidal neurons of young and adult rat hippocampus. Fiziol $\mathrm{Zh}$. $2015 ; 61: 5-10$

7. Lee CJ, Mannaioni G, Yuan H, Woo DH, Gingrich MB, Traynelis SF. Astrocytic control of synaptic NMDA receptors. J Physiol. 2007; 581:1057-81.

8. Maggio N, Cavaliere C, Papa M, Blatt I, Chapman J, Segal M. Thrombin regulation of synaptic transmission: Implications for seizure onset. Neurobiol Dis. 2013; 50:171-8.

9. Almonte AG, Qadri LH, Sultan FA, Watson JA, Mount DJ, Rumbaugh G, Sweatt JD. Protease-activated receptor-1 modulates hippocampal memory formation and synaptic plasticity. J Neurochem. 2013; 124:109-22.

10. Almonte AG, Hamill CE, Chhatwal JP, Wingo TS, Barber JA, Lyuboslavsky PN, David Sweatt J, Ressler KJ, White DA, Traynelis SF. Learning and memory deficits in mice lacking protease activated receptor-1. Neurobiol Learn Mem. 2007; 88:295-304.

11. Striggow F, Riek M, Breder J, Henrich-Noack P, Reymann $\mathrm{KG}$, Reiser $\mathrm{G}$. The protease thrombin is an endogenous mediator of hippocampal neuroprotection against ischemia at low concentrations but causes degeneration at high concentrations. Proc Natl Acad Sci. 2000; 97:2264-9.

12. Olson EE, Lyuboslavsky P, Traynelis SF, McKeon RJ. PAR-1 Deficiency Protects Against Neuronal Damage and Neurologic Deficits After Unilateral Cerebral Hypoxia/ Ischemia. J Cereb Blood Flow Metab. 2004; 24:964-71.

13. Yan J, Manaenko A, Chen S, Klebe D, Ma Q, Caner
B, Fujii M, Zhou C, Zhang JH. Role of SCH79797 in maintaining vascular integrity in rat model of subarachnoid hemorrhage. Stroke. 2013; 44:1410-7.

14. Xi G, Reiser G, Keep RF. The role of thrombin and thrombin receptors in ischemic, hemorrhagic and traumatic brain injury: Deleterious or protective? J Neurochem. 2003; 84:3-9.

15. Glien M, Brandt C, Potschka H, Voigt H, Ebert U, Löscher W. Repeated low-dose treatment of rats with pilocarpine: low mortality but high proportion of rats developing epilepsy. Epilepsy Res. 2001; 46:111-9.

16. Racine R, Okujava V, Chipashvili S. Modification of seizure activity by electrical stimulation: II. Motor Seizure. Electroencephalogr Clin Neurophysiol. 1972; 32:295-9.

17. Brandt C, Gastens AM, Sun M zhen, Hausknecht M, Löscher W. Treatment with valproate after status epilepticus: effect on neuronal damage, epileptogenesis, and behavioral alterations in rats. Neuropharmacology. 2006; 51:789-804.

18. Brandt C, Glien M, Gastens AM, Fedrowitz M, Bethmann K, Volk HA, Potschka H, Löscher W. Prophylactic treatment with levetiracetam after status epilepticus: Lack of effect on epileptogenesis, neuronal damage, and behavioral alterations in rats. Neuropharmacol. 2007; 53:207-21.

19. Polascheck N, Bankstahl M, Löscher W. The COX-2 inhibitor parecoxib is neuroprotective but not antiepileptogenic in the pilocarpine model of temporal lobe epilepsy. Exp Neurol. 2010; 224:219-33.

20. Rice AC, Floyd CL, Lyeth BG, Hamm RJ, DeLorenzo RJ. Status epilepticus causes long-term NMDA receptordependent behavioral changes and cognitive deficits. Epilepsia. 1998; 39:1148-57.

21. Bröer S, Löscher W. Novel combinations of phenotypic biomarkers predict development of epilepsy in the lithium-pilocarpine model of temporal lobe epilepsy in rats. Epilepsy Behav. 2015; 53:98-107.

22. Bogovyk R, Lunko O, Fedoriuk M, Isaev D, Krishtal O, Holmes GL, Isaeva E. Effects of protease-activated receptor 1 inhibition on anxiety and fear following status epilepticus. Epilepsy Behav. 2017; 67:66-9.

23. Brandt C, Nozadze M, Heuchert N, Rattka M, Löscher W. Disease-Modifying Effects of Phenobarbital and the NKCC1 Inhibitor Bumetanide in the Pilocarpine Model of Temporal Lobe Epilepsy. J Neurosci. 2010; 30:8602-12.

24. Brandt C, Rankovic V, Töllner K, Klee R, Bröer S, Löscher W. Refinement of a model of acquired epilepsy for identification and validation of biomarkers of epileptogenesis in rats. Epilepsy Behav. 2016; 61:120-31.

25. Huang X, McMahon J, Huang Y. Rapamycin attenuates aggressive behavior in a rat model of pilocarpine-induced epilepsy. Neurosci. 2012; 215:90-7.

26. Schauwecker PE. Strain differences in seizure-induced cell death following pilocarpine-induced status epilepticus. Neurobiol Dis. 2012; 45:297-304.

27. Brandt C, Bankstahl M, Töllner K, Klee R, Löscher W. The pilocarpine model of temporal lobe epilepsy: Marked 
The protease-activated receptor 1 inhibition during epileptogenesis does not alter behavioral excitability in rats

intrastrain differences in female Sprague-Dawley rats and the effect of estrous cycle. Epilepsy Behav. 2016; 61:14152.

28. Lekic T, Klebe D, McBride DW, Manaenko A, Rolland WB, Flores JJ, Altay O, Tang J, Zhang JH. ProteaseActivated Receptor 1 and 4 Signal Inhibition Reduces
Preterm Neonatal Hemorrhagic Brain Injury. Stroke. 2015; 46:1710-3.

29. Huang X, Zhang H, Yang J, Wu J, McMahon J, Lin Y, Cao Z, Gruenthal M, Huang Y. Pharmacological inhibition of the mammalian target of rapamycin pathway suppresses acquired epilepsy. Neurobiol Dis. 2010; 40:193-9.

Received 21.11.2017 